Sherlock, Dean of St. Paul's, scores 121 entries; Bishop Jeremy Taylor, 138; and Bishop Edward Stillingfleet, 123. Yet the palm for the greatest number of entries goes to that unappeasable pamphleteer, William Prynne, with 344. William Penn, no unprolific writer himself, comes up with 153 .

Being an age of civil war and its aftermath, thousands of pamphlets appeared anonymously. The anonymous pamphleteer, however, displayed a singular lack of originality in his titles. There are 107 entries beginning with "Short," "A Short Way," "A Short Relation," "A Short Cut"; there were 53 "Seasonables," I 3 I "Reasons," I I I "Stranges," and no less than 806 beginning with the word "True." These were the key words.

Seldom does any book deserve the too much abused description of "indispensable." Wing does deserve it. All scholars of i 7 th century England, and all the librarians who serve them, have already recognized what it means to have easily and accurately available a list of all books and pamphlets printed in the period, and their dependence on Wing will grow in the years to come. If the Index Society never sponsors another "index," it will have justified its formation by the publication of Wing.-Stanley Pargellis, The Newberry Library.

\section{Studies in Bibliography}

Studies in Bibliography. Papers of the Bibliographical Society of the University of Virginia. Edited by Fredson Bowers. Vol. 4, 195I/52, Charlottesville. (\$6.0o, free to members.)

A wondrous sight, familiar to many librarians, is that of mortification being publicly performed en masse by the initiates of a bibliographical society. I refer to the custom of their meetings at which on fidget-hard chairs or soporific seats the membership is expected to assimilate audially papers which are visual in their appeal. The Bibliographical Society (London) and its American counterpart are confirmed practitioners of this traditional rite, and I am rather certain that if one were to suggest to their officers that meetings should be devoted entirely to visual representation of bibliographical topics-exhibits, slides, etc.the heretic would be quickly water-marked and sent down river.
Five years ago a hopeful augury was the founding of a new bibliographical society at the University of Virginia, and although one of its founding high priests, Professor Fredson Bowers, personifies the apotheosis of Scientific Bibliography, humanistic amelioration was furnished by his co-founding fellow Virginians, John Cook Wyllie, Jack Dalton and Linton Massey.

The papers gathered into print in Volume 4 are a nice blend of historical and statistical bibliography and of British, Continental and American topics. Shakespeare is the subject of four contributions; the moderns include Sherwood Anderson and T. S. Eliot. Useful feature is a "Selective Checklist of Bibliographical Scholarship" compiled by Hirsch and Heaney. Issuance of a bound annual volume has advantages over quarterly papers, such as those published by the Bibliographical Society of America, which are awkward to use in parts and increasingly costly to bind.

Publication of these studies is but one of the activities of this lively Virginia group. They also sponsor a student book collectors' contest, and a contest for the best printing in Virginia. The Society richly deserves the world-wide interest it has elicited.-Lawrence Clark Powell, University of California Library, Los Angeles.

\section{Library Trends}

Library Trends, Volume I, Number I, July 1952. University of Illinois Library School, Urbana, Illinois. Quarterly. \$5.00 per year.

Library Trends is the new quarterly of the University of Illinois Library School. It is the outcome of a four-year study of the available library literature by the school's faculty and marks its decision that there was a place for a new professional journal-a journal which would "present in each issue a synthesis and evaluation of a single topic relating to librarianship ... review and evaluate current practice and current thinking in librarianship ... [and] be even more concerned with the probable future of such current developments in librarianship."

"Current Trends in College and University Libraries" is the subject of the first number (July, 1952). In a brief introduction, the editor of this issue, Robert B. Downs, sum- 